\title{
The Effect of Earnings Management on Liquidity Criteria and Lack of Liquidity Stock
}

\author{
Mohammad Hossein Vadiei Nowghabi ${ }^{1}$, Ali Shirazd ${ }^{2}$, Shaban Mohammadi ${ }^{3}$, \\ Alireza Khorshidi ${ }^{4}$ \\ ${ }^{1}$ Associate Professor Ferdowsi University of Mashhad, Iran \\ ${ }^{2}$ Ph.D student Ferdowsi University of Mashhad, Iran \\ ${ }^{3}$ M.A student in accounting, Hakim Nezami University, Quchan, Iran \\ ${ }^{4}$ M.A student in accounting, Iran \\ E-mail address: Shaban1362@gmail.com
}

Keywords: Accrual-based earnings management, the actual management profit, stock liquidity.

\begin{abstract}
Liquidity criteria that investors in making portfolio investments are involved. Among the factors that could affect liquidity, earnings management. Earnings management can accrualbased earnings management aspects and management of real benefit to be evaluated; Therefore, the aim of this study is to estimate the accrual-based earnings management and gain real management and its effects on liquidity of companies listed on the Stock Exchange in Tehran. The sample consisted of 78 companies for the period 2008 to 2012. We used multivariate regression model based on panel data is performed. Our results show that research hypotheses are tested between accrual-based earnings management positive and significant relationship with the lack of liquidity, and the liquidity and significant negative relationship. As well as the actual management of nonprofit with a positive and significant relationship between stock liquidity, and the liquidity is insignificant and there is a negative relationship.
\end{abstract}

\section{INTRODUCTION}

In general, two types of response to the data may occur in the market: the first reaction, the effect of price information on securities, and the market response to volume. The work on indicators of "liquidity" appears [1]. In general, liquidity is the ease of buying and selling a product without a significant change in its price. One of the characteristics of an ideal efficient market and lack of liquidity due to high transaction costs and, therefore, can be a measure of the efficiency of market liquidity, particularly in terms of the information presented. As providing useful information in order to investigate the factors influencing apply. With increased liquidity, transaction costs will drop dramatically. Liquidity also plays an important role in the price discovery process. The concept of fledgling markets such as market liquidity in Iran is very important. The results of research in the field of liquidity in the securities market is Iran, show that investors illiquidity risk in their decisions in terms of their intensity. after investigating the factors affecting the liquidity of the utmost importance. Among the factors that could affect liquidity, earnings management. As the company's earnings management in selecting accounting policies to achieve some specific goals defined administrator. Recognize the benefits of it can be stated that the researchers have shown that earnings management is usually transparent to investors. The interests of a firm may use earnings management through greater disclosure and litigation costs are expected to be neutral, therefore, the identification of existence and the continuation of the company's management in favor of the validity reduced. ability to raise capital subsequent to weaken and destroy the favorable conditions. In this study, we examine the effect of earnings management on liquidity and lack of liquidity of the stocks examined. 


\section{LITERATURE REVIEW}

Liquidity as the ability to buy and sell the required quantity of securities at market prices and in a short time period is defined. This feature is valuable so on equal terms, securities with higher liquidity than securities with lower liquidity, higher price will be [8]. Liquidity is the ability to convert to cash quickly and without reducing the price of a financial instrument. Liquidity is the ability to trade a financial instrument at a price (market price) and in large volumes without disrupting the market provides. Once considered an asset that an investor can be liquidated without causing a change in the market price, a lot of it is not traded. Therefore, liquidity risk can be defined transaction at a price equivalent to the price of the previous transaction. Liquidity is an important criterion in the market. In addition, the market price movements are slow and the gap between bid and offer prices close to zero. Overall, earnings management is possible in two ways: earnings management billing based on actual profit figures. In the first case management through discretionary accruals accounting figures in accordance with the objectives desired to make deals. In the second case, management has made some operational decisions, in other words the real thing to the actual management activity earns profit on their desired change. The overall management of the profit follows:

A) Manipulate real activities

B) Manipulation of discretionary accruals.

The definition of the actual management of interest: [11] in their study stated that earnings management can include the actual activities. This type of earnings management through changes in operational activities aimed at misleading the stakeholders. cash manipulation of real activity and in some cases the impact accruals. The definition of accrual-based earnings management: Because of the flexibility of generally accepted accounting principles, management uses various methods adopted, is trying to say in accruals. Regarding the quality of information management can increase profits by reporting confidential information. The difference between the motivations of managers and shareholders, may force managers to use flexibility generally accepted accounting principles, profit managed to win and therefore reported earnings to be diverted [7]. one of the characteristics of efficient markets and not ideal, high transaction costs and thus liquidity. Accounting is a source of information that can provide relevant information and reliable, less inefficiency and information, thereby improving liquidity conditions and market shares are more effective. It can be used as a measure of liquidity of stock market performance, particularly in terms of the information and forms in order to investigate the factors influencing the useful information to be used [1].Increased liquidity could further divide the financial risk of the portfolio by reducing the cost of overestimating Investors in their trading decisions and increase sales of their stock, which ultimately leads to an increase in the company. The concept of liquidity in nascent markets like the market is far more important. The results are in stock liquidity in the securities market is Iran, suggest that investor's illiquidity risk in their decisions in terms of their intensity. Among the factors that could affect liquidity, earnings management [12]. As the company's earnings management in selecting accounting policies to achieve some specific goals defined administrator. Therefore, evaluating the factors affecting Liquidity called earnings management in the real commitment in this regard is of great importance. In this study, we sought to examine the effect of earnings management on stock liquidity and illiquidity are stock. The elements of intellectual capital and its components, and models comments have been presented by the scientists. It seems that the intellectual capital literature review, most existing models have attempted to three components of intellectual capital with some common features to consider: Human Capital: Human capital is a combination of knowledge, skills, innovation ability, the ability of employees to perform their duties, values, culture and philosophy of the company. Human capital and intellectual capital essential foundation for the realization of the intellectual capital inhibits definition [2]. Capital structure is everything when employees go home remain in the company [3]. Customer funds: customer funds as a bridge and catalyst activity is intellectual capital [9]. The main requirements for determining the market value and thus become the intellectual capital of the company's business performance. Customer capital is 
one of the main components of intellectual capital is the value of marketing and communication channels with leaders of industry and trade, it is. New definitions of capital assets related to customer relationships have developed, including knowledge of the company with customers, competitors, suppliers and governmental factors [2].

\section{RESEARCH HYPOTHESES}

According to theoretical principles mentioned hypotheses can be expressed as follows:

1. The accrual-based earnings management, and has a significant negative impact on stock liquidity.

2. Real-profit management and significant negative impact on stock liquidity. In this study, two hypotheses with two criteria are liquidity and illiquidity review.

\section{RESEARCH METHODOLOGY}

The study population consisted of all companies listed in Tehran Stock Exchange since the beginning of 2008 until the end of 2012. During this period they also retained his membership on the stock exchange. Because of the disparate nature of some community members to submit samples taken following restrictions: Companies that since 2008 have been accepted in exchange. Financial year ended 29 March. Company shares trade gap is not more than 100 days. Required data exchange databases are available databases, Company financial period has not changed. Finally, 78 companies for the period 2008 to 2012 have been selected. In this study, data collection takes place in two stages. Firstly, to develop theoretical foundations of research, the library and the second phase of data collection tool documentation or the use of forms and databases is mining. Actual and historical data used in this study is that the Tehran Stock Exchange website, company financial statements and the text will be extracted from the database.

\subsection{The research model and how to obtain the variables}

Based on previous research and theoretical basis of the following regression to assess the relationship between earnings management and administration of real benefit accruals based on the following:

$\mathrm{Pzr}=\alpha_{0}++\alpha_{1} \mathrm{AM}+\alpha_{3} \operatorname{lnmve}+\alpha_{4} \mathrm{NT}+\alpha_{5} \mathrm{Cum}+\varepsilon_{i t}$

$\mathrm{Pzr}=\alpha_{0}++\alpha_{1} R M+\alpha_{3} \operatorname{lnmve}+\alpha_{4} \mathrm{NT}+\alpha_{5} \mathrm{Cum}+\varepsilon_{i t}$

Of days with zero output (pzr): To calculate the proportion of days with zero return, should the number of days with zero efficiency for a particular stock on the number of days since the company's stock is traded on it are divided, which is calculated way or another.

AM: accrual-based earnings management

RM: actual management profit

Lnmve: natural logarithm value of ordinary shares at end of period

NT: number of shares traded per year

Cum: Cumulative returns the last six months

$\ln (\$$ volume $)=\alpha_{0}++\alpha_{1} \mathrm{AM}+\alpha_{3} \operatorname{lnmve}+\alpha_{4} \mathrm{NT}+\alpha_{5} \mathrm{Cum}+\varepsilon_{i t}$

$\ln (\$$ volume $)=\alpha_{0}++\alpha_{1} \mathrm{RM}+\alpha_{3} \operatorname{lnmve}+\alpha_{4} \mathrm{NT}+\alpha_{5} \mathrm{Cum}+\varepsilon_{i t}$

The average value of the rial trading $\ln (\$$ volume): Data for this measure by dividing the total daily value of transactions in the company and the company deal comes days.

\subsection{Independent variables}

Accrual-based earnings management: Because of the flexibility of generally accepted accounting principles, management uses various methods adopted, is trying to say in accruals. Quality of information management practices can reduce profits due to earnings manipulation. Management benefit accruals-based measure of discretionary accruals is used. To estimate 
discretionary accruals from the regression model used in both of the remaining regression equation $(\varepsilon)$ represents the accrual is optional: Jones modified model:

Model 4:

TAccrt $/$ Assetst- $1=\alpha+\beta 01 /$ Assetst- $1+\beta 1(\Delta$ Salest $-\Delta$ RECit $) /$ Assetst- 1

+ B2 PPEt / Assetst-1 + $\beta 3$ ROAt-1 + $\beta 4 \mathrm{SGt}+\varepsilon \mathrm{t}$

Model 4, the modified Jones model by [3] and then: TAccrt / Assets t-1: the difference between profit before extraordinary items and cash flow from operating activities in the current period. Assetst-1: Total assets at the beginning of the financial period. $\Delta$ sale: changes in sales. $\Delta$ Rec: Changes in receivables. PPE: Property, machinery and equipment. ROA: Net income divided by total assets, and SG: growth is now on sale.

TAccrt /Assetst $-1=\alpha+\beta 01 /$ Assetst $1+\beta 1(\Delta$ Salest $-\triangle R E C i t) /$ Assetst-1

$+\beta 2$ PPEt/Assetst $-1+\beta 3$ ROAt $-1+\beta 4 S G t+\varepsilon_{\mathrm{t}}$

Kothari and his colleagues have developed a model that was similar but modified Jones model in which the rate of return on assets was used. In their study they found that the model results are stronger than the Jones. Their model was as follows [9]:

Model 5:

$T A_{i t} / A_{i t-1}=\alpha_{1}\left(1 / A_{i t-1}\right)+\alpha_{2}\left(\Delta R E V_{i t} / A_{i t-1}\right)+\alpha_{3}\left(P P E_{i t} / A_{i t-1}\right)+\alpha_{4} R O A_{i t-1}+\varepsilon_{i t}$

\subsection{Real-profit management}

Management practices that are associated with ordinary commercial activities, and in conjunction with the primary aim to meet certain income thresholds, are performed [10]. measuring actual profit management. In this research, including research [10] and [2] to measure the level of real activity manipulation of three criteria unusual level of operating cash flow, level of abnormal production costs and the level of discretionary spending is unusual. To measure these three criteria used by the regression model and all of the remaining regression $(\varepsilon)$ indicates an abnormal level variables are estimated:

Model 6:

$\mathrm{CFO}_{\mathrm{it}} /$ Assets $_{\mathrm{I}, \mathrm{t}-1}=\mathrm{K}_{1 \mathrm{t}}\left(1 /\right.$ Assets $\left._{\mathrm{I}, \mathrm{t}-1}\right)+\mathrm{K}_{2 \mathrm{t}}\left(\operatorname{Sales}_{\mathrm{it}} /\right.$ Assets $\left._{\mathrm{I}, \mathrm{t}-1}\right)+\mathrm{K}_{3 \mathrm{t}}\left(\Delta\right.$ Sales $_{\mathrm{it}} /$ Assets $\left._{\mathrm{I}, \mathrm{t}-1}\right)+\varepsilon_{\mathrm{it}}$

CFOit: operating cash flow in period t.

Model 7:

PROUD $_{\mathrm{it}} /$ Assets $_{\text {I, }} \mathrm{t}-1=\mathrm{K}_{1 \mathrm{t}}\left(1 /\right.$ Assets $\left._{\text {I, }} \mathrm{t}-1\right)+\mathrm{K}_{2 \mathrm{t}}\left(\operatorname{Sales}_{\mathrm{it}} /\right.$ Assets $\left._{\text {I, }} \mathrm{t}-\mathrm{H}\right)+\mathrm{K}_{3 \mathrm{t}}\left(\Delta\right.$ Sales $_{\mathrm{it}} /$ Assets $\left._{\text {I, }} \mathrm{t}-1 \quad\right)$ $+\mathrm{K}_{4 \mathrm{t}}\left(\Delta\right.$ Sales $_{\mathrm{I}, \mathrm{t}-1} /$ Assets $\left._{\mathrm{I}, \mathrm{t}-1}\right)+\varepsilon_{\mathrm{it}}$

PROUDit: production costs in period $t$ shows the total cost of an item is sold and changes in inventory.

Model 8:

DiscExpit/Assets I, t-1=K1t(1/Assets I, t-1 (+K2t(Sales I, t-1/Assets I, t-1 )+عit

DiscExpit: optional costs in period $t$ are the sum of the cost of advertising, general sales and administrative costs of the organization. Get real benefit for variable management, the remaining three equations, regression $(\varepsilon)$ of high standard and variable management together to achieve real profits [5].

\subsection{Dependent variable:}

Liquidity: liquidity as the ability to buy and sell the required quantity of securities at market prices and in a short time period is defined. This feature is valuable so on equal terms, securities with higher liquidity than securities with lower liquidity will be more expensive. [4]. Days with zero efficiency ratios (pzr): theoretical foundations provided liquidity index and it was used. In their view, if the value of the information signal does not exceed the value of the transaction costs, 
market participants do not buy or sell is zero, so returns. Therefore, the higher the level of transaction costs, provide more daily returns zero. To calculate the efficiency ratio to zero days, zero should yield the number of days for a particular stock on the number of days since the company's stock is traded on it are divided, which is calculated way or another. This ratio is more indicative of the lack of liquidity is more relevant to its shares. Icon of days with zero returns for stock i. Zrd is the equivalent of a day if it returns of stock $i$ is zero, otherwise zero. the number of trading days of the stock $\mathrm{i}$ in the financial year. Benchmark average monetary value of transactions (lnvolume): This measures the trading liquidity of the trading volume and sightseeing. These measures are defined as volume or quantity of shares when calculated per unit and are often an indication of the depth of liquidity. The criteria related to higher volumes, and higher liquidity.

\subsection{Control variables}

lnmve: natural logarithm value of ordinary shares at the end of the period. Nt: number of shares traded per year. Cum: Cumulative returns the last six months. The model for the $R O A_{\text {it }-1}$ fruiting rate assets in year $\mathrm{t}-1$ is.

\section{DATA ANALYSIS}

Central tendency and dispersion is provided in Table 1. The difference between minimum and maximum data indicates scope for the use of variables. The appropriate amount represents the standard deviation data integrity of the sample is appropriate. The mean and median are few variables reflect their enjoyment of a normal distribution.

Table 1: Descriptive statistics of central tendency and dispersion

\begin{tabular}{|c|c|c|c|c|c|c|}
\hline $\begin{array}{c}\text { standard } \\
\text { deviation }\end{array}$ & minimum & maximum & Middle & Average & $\begin{array}{c}\text { variable } \\
\text { symbol }\end{array}$ & Variable \\
\hline $0 / 09617$ & $0 / 0000$ & $0 / 8100$ & $0 / 0600$ & $0 / 0877$ & $\mathrm{PZR}$ & Criterion Lack liquidity \\
\hline $1 / 7894$ & $-3 / 5083$ & $11 / 3107$ & $-0 / 3251$ & $-0 / 0472$ & $\mathrm{RM}$ & Actual management profit \\
\hline $1 / 1237$ & $-5 / 5017$ & $3 / 4507$ & $0 / 1077$ & $0 / 3073$ & $\mathrm{AM} 1$ & Accrual-based earnings management (Jones( \\
\hline $0 / 8007$ & $-5 / 5235$ & $2 / 4154$ & $0 / 0683$ & $0 / 0521$ & $\mathrm{AM} 2$ & $\begin{array}{c}\text { was higher earnings } \\
\text { management accruals (Kothari) }\end{array}$ \\
\hline 32797 & 588 & 171434 & 7811 & $22043 / 23$ & $\mathrm{NT}$ & $\begin{array}{c}\text { Number of shares in } \\
\text { transaction }\end{array}$ \\
\hline $1 / 5389$ & $11 / 9086$ & $18 / 9259$ & $13 / 8360$ & $14 / 3397$ & LnMv & $\begin{array}{c}\text { Natural logarithm value of } \\
\text { ordinary shares at end of } \\
\text { period }\end{array}$ \\
\hline $1 / 6028$ & $17 / 2756$ & $27 / 1835$ & $20 / 8176$ & $21 / 0194$ & $\begin{array}{c}\text { Volume } \\
\text { Ln }\end{array}$ & \begin{tabular}{c} 
Liquidity criteria \\
\hline $0 / 4533$
\end{tabular} \\
\hline & $0 / 0000$ & $5 / 5619$ & $0 / 9084$ & $0 / 9832$ & Cum & $\begin{array}{c}\text { Cumulative returns the last six } \\
\text { months }\end{array}$ \\
\hline
\end{tabular}

\subsection{Test assumptions.}

Due to the use of combined data analysis model to evaluate the data from this study in the first stage of this research will be discussed. The question that comes to an estimate using panel data is a must from which the panel or classic method used. F-Limer first test to determine the data we used classical or panel. If you choose the second stage of the selection panel data either way the decision should be fixed or random, usually Hausman test is used for that purpose. For each hypothesis and research model of this type of data in Table 2 below: 
Table 2: The type of data for this research hypotheses and models

\begin{tabular}{|c|c|c|}
\hline hypotheses & F test & Hausman test \\
\hline $\begin{array}{c}\text { The first hypothesis (Jones model } \\
\text { and a measure of liquidity) }\end{array}$ & Panel method & Random effects \\
\hline $\begin{array}{c}\text { The first hypothesis (model } \\
\text { Kothari and a measure of } \\
\text { liquidity) }\end{array}$ & Panel method & Fixed method \\
\hline $\begin{array}{c}\text { The first hypothesis (Jones model } \\
\text { and liquidity criteria }\end{array}$ & Panel method \\
\hline $\begin{array}{c}\text { The first hypothesis (model } \\
\text { Kothari and liquidity criteria) }\end{array}$ & Panel method & Fixed method \\
\hline $\begin{array}{c}\text { The second hypothesis (the actual } \\
\text { management of earnings and a } \\
\text { measure of liquidity) }\end{array}$ & Panel method & Fixed method \\
\hline $\begin{array}{c}\text { The second hypothesis (the actual } \\
\text { management of interest and } \\
\text { liquidity criteria) }\end{array}$ & Panel method \\
\hline
\end{tabular}

In the regression analysis is more to performance regression assumptions are examined. Check consistency error variance components to investigate heterogeneity of variance in the data panel, Wald test, adjusted by Green has been used. The results in Table 3 below.

Table 3: Check consistency error variance components

\begin{tabular}{|l|l|l|l|l|}
\hline Assumptions (models) & $\begin{array}{l}\text { Null } \\
\text { hypothesis }\end{array}$ & $\begin{array}{l}\text { Statistics } \\
\chi^{2}\end{array}$ & p-value & test results \\
\hline $\begin{array}{l}\text { The first hypothesis (Jones } \\
\text { model and a measure of } \\
\text { liquidity) }\end{array}$ & $\begin{array}{l}\text { Harmony } \\
\text { variance } \\
\text { (ANOVA } \\
\text { inconsistency } \\
\text { exists) }\end{array}$ & $5.7 \mathrm{e}+33$ & 0.000 & $\begin{array}{l}H_{0} \text { Passes (there } \\
\text { is a variance } \\
\text { heterogeneity) }\end{array}$ \\
\hline $\begin{array}{l}\text { The first hypothesis (model } \\
\text { Kothari and a measure of } \\
\text { liquidity) }\end{array}$ & $\begin{array}{l}\text { Harmony } \\
\text { variance } \\
\text { (ANOVA } \\
\text { inconsistency } \\
\text { exists( }\end{array}$ & $20 / 03$ & 0.000 & $\begin{array}{l}H_{0} \text { Passes (there } \\
\text { is a variance } \\
\text { heterogeneity) }\end{array}$ \\
\hline $\begin{array}{l}\text { The first hypothesis (Jones } \\
\text { model and a measure of } \\
\text { liquidity) }\end{array}$ & $\begin{array}{l}\text { Harmony } \\
\text { variance } \\
\text { (ANOVA } \\
\text { inconsistency } \\
\text { exists) }\end{array}$ & $4.3 \mathrm{e}+33$ & 0.000 & $\begin{array}{l}H_{0} \text { Passes (there } \\
\text { is a variance } \\
\text { heterogeneity) }\end{array}$ \\
\hline $\begin{array}{l}\text { The first hypothesis (model } \\
\text { Kothari and a measure of } \\
\text { liquidity( }\end{array}$ & $\begin{array}{l}\text { Harmony } \\
\text { variance } \\
\text { (ANOVA } \\
\text { inconsistency } \\
\text { exists) }\end{array}$ & $2.9 \mathrm{e}+30$ & 0.000 & $\begin{array}{l}H_{0} \text { Passes (there } \\
\text { is a variance } \\
\text { heterogeneity) }\end{array}$ \\
\hline $\begin{array}{l}\text { The second hypothesis } \\
\text { theactual management of } \\
\text { earnings and a measure of } \\
\text { liquidity) }\end{array}$ & $\begin{array}{l}\text { Harmony } \\
\text { variance } \\
\text { (ANOVA } \\
\text { inconsistency } \\
\text { exists) }\end{array}$ & $2.0 \mathrm{e}+34$ & 0.000 & $\begin{array}{l}\text { Harmony } \\
\text { variance } \\
\text { (ANOVA } \\
\text { inconsistency } \\
\text { exists) }\end{array}$ \\
\hline $\begin{array}{l}\text { The second hypothesis } \\
\text { theactual management of } \\
\text { earnings and a measure of } \\
\text { liquidity) }\end{array}$ & $8.3 \mathrm{e}+32$ & 0.000 & $\begin{array}{l}H_{0} \text { Passes (there } \\
\text { is a variance } \\
\text { heterogeneity) }\end{array}$ \\
\hline
\end{tabular}


As you can see in Figure 3 and 4 for every 2 model used in this study because the probability is less than 0.05 , Therefore, the null hypothesis that the variance homogeneity and heterogeneity of variance is rejected. To fix the inconsistency of the variance in estimates used white correction. The correlation between the components of error to analyze the relationship between error components Valdryj test is used. The value of this statistic for each model is presented in Table 4.

Table 4: The correlation between the components of the error

\begin{tabular}{|c|c|c|c|}
\hline Assumptions (models) & p-value & Null hypothesis & test results \\
\hline $\begin{array}{c}\text { The first hypothesis } \\
\text { (Jones model and a } \\
\text { measure of liquidity) }\end{array}$ & $0 / 0003$ & There is no correlation & $\begin{array}{c}\text { The null hypothesis is } \\
\text { rejected }\end{array}$ \\
\hline $\begin{array}{c}\text { The first hypothesis } \\
\text { (model Kothari and a } \\
\text { measure of liquidity) }\end{array}$ & $0 / 0003$ & There is no correlation & $\begin{array}{c}\text { The null hypothesis is } \\
\text { rejected }\end{array}$ \\
\hline $\begin{array}{c}\text { The first hypothesis } \\
\text { (Jones model and a } \\
\text { measure of liquidity) }\end{array}$ & $0 / 9924$ & There is no correlation & $\begin{array}{c}\text { The null hypothesis is } \\
\text { confirmed. }\end{array}$ \\
\hline $\begin{array}{c}\text { The first hypothesis } \\
\text { (model Kothari and a } \\
\text { measure of liquidity) }\end{array}$ & $0 / 9699$ & There is no correlation & $\begin{array}{c}\text { The null hypothesis is } \\
\text { confirmed. }\end{array}$ \\
\hline $\begin{array}{c}\text { The second hypothesis } \\
\text { (theactual management } \\
\text { of earnings and a } \\
\text { measure of liquidity) }\end{array}$ & $0 / 000$ & There is no correlation & $\begin{array}{c}\text { The null hypothesis is } \\
\text { rejected }\end{array}$ \\
\hline $\begin{array}{c}\text { The second hypothesis } \\
\text { (the actual management } \\
\text { of earnings and a } \\
\text { measure of liquidity) }\end{array}$ & $0 / 9275$ & There is no correlation & $\begin{array}{c}\text { The null hypothesis is } \\
\text { confirmed. }\end{array}$ \\
\hline
\end{tabular}

The lack of alignment between variables to examine the lack of alignment between the variables of Variance Inflation Factor (VIF) is used to estimate the variables presented in the table with the results indicate a lack of co-linearity between models.

Table 5: The lack of alignment between the variables

\begin{tabular}{|c|c|c|c|c|}
\hline \multicolumn{5}{|c|}{$\mathrm{PZR}=\alpha_{0}++\alpha_{1} \mathrm{AM}+\alpha_{3}$ lnmve $+\alpha_{4} \mathrm{NT}+\alpha_{5} \mathrm{Cum}+\varepsilon_{\mathrm{it}}$} \\
\hline \multicolumn{5}{|c|}{$\begin{array}{l}\text { The first hypothesis } \\
\text { (Accrual-based earnings management based on modified Jones model and a measure of liquidity) }\end{array}$} \\
\hline VIF & P-value & T statistic & Variable factor & Variable \\
\hline- & $0 / 003$ & $2 / 96$ & $0 / 1530$ & Source width \\
\hline $1 / 01$ & $0 / 000$ & $4 / 51$ & $0 / 0379$ & $\begin{array}{c}\text { Management commitment } \\
\text { profit (adjusted Jones } \\
\text { model) }\end{array}$ \\
\hline $1 / 01$ & $0 / 224$ & $-1 / 22$ & $-0 / 0044$ & $\begin{array}{c}\text { Natural logarithm value of } \\
\text { ordinary shares at end of } \\
\text { period }\end{array}$ \\
\hline $1 / 01$ & $0 / 010$ & $-2 / 58$ & $-0 / 00008$ & NT \\
\hline $1 / 01$ & $0 / 729$ & $0 / 35$ & $0 / 0033$ & Cum \\
\hline \multicolumn{4}{|c|}{$0 / 000$} & Probability of F statistics \\
\hline \multicolumn{4}{|c|}{$46 / 79$} & F statistic \\
\hline \multicolumn{4}{|c|}{ 0/1981 } & $\begin{array}{c}\text { Adjusted coefficient of } \\
\text { determination }^{2}\end{array}$ \\
\hline
\end{tabular}


As in Table 5 is an observation, a significant level of earnings management variables obligations (0.000) and coefficient (0.0397) is. As a result, the first hypothesis at a significance level of $95 \%$ is approved. This means that the variable accrual-based earnings management has a direct correlation with the lack of liquidity is variable, It means that the accrual-based earnings management level in a company is most likely the lack of liquidity also increased. Our results are similar to most studies. $[1,2]$ in their study concluded that by increasing the level of accrual-based earnings management, the probability of increased stock liquidity.

Table 6: Consequently, the first hypothesis

\begin{tabular}{|c|c|c|c|c|}
\hline \multicolumn{5}{|c|}{$\mathrm{PZR}=\alpha_{0}++\alpha_{1} \mathrm{AM}+\alpha_{3} \operatorname{lnmve}+\alpha_{4} \mathrm{NT}+\alpha_{5} \mathrm{Cum}+\varepsilon_{\mathrm{it}}$} \\
\hline \multicolumn{5}{|c|}{$\begin{array}{l}\text { The first hypothesis } \\
\text { (Accrual-based earnings management model and a measure of liquidity Kunar) }\end{array}$} \\
\hline VIF & P-value & T statistic & Variable factor & Variable \\
\hline- & $0 / 004$ & $2 / 92$ & $0 / 2081$ & Source width \\
\hline $1 / 01$ & $0 / 000$ & $6 / 10$ & $0 / 0497$ & $\begin{array}{c}\text { Accrual earnings } \\
\text { management (Kothari) }\end{array}$ \\
\hline $1 / 02$ & $0 / 222$ & $-1 / 23$ & $-0 / 0059$ & $\begin{array}{l}\text { Natural logarithm value of } \\
\text { ordinary shares at end of } \\
\text { period }\end{array}$ \\
\hline $1 / 01$ & $0 / 000$ & $-5 / 00$ & $-0 / 00001$ & NT \\
\hline $1 / 01$ & $0 / 04$ & $0 / 04$ & $0 / 0005$ & Cum \\
\hline \multicolumn{4}{|c|}{$0 / 000$} & Probability of F statistics \\
\hline \multicolumn{4}{|c|}{$23 / 69$} & F statistic \\
\hline \multicolumn{4}{|c|}{$0 / 1413$} & $\begin{array}{l}\text { Adjusted coefficient of } \\
\text { determinationR }\end{array}$ \\
\hline
\end{tabular}

As in Table 6 can be seen, a significant level variable gain management commitment $(0.000)$ and coefficient (0.0497) is. As a result, the first hypothesis based on accrual-based earnings management Kothari is measured at a significance level of $95 \%$ is approved. This means that the variable accrual-based earnings management has a direct correlation with the lack of liquidity is variable, namely the level of accrual-based earnings management in a company is most likely increases the lack of liquidity. Our results are similar to most studies. [1,2] in their study concluded that by increasing the level of accrual-based earnings management, the probability of increased stock liquidity.

Table 7: Measuring stock liquidity

\begin{tabular}{|c|c|c|c|c|}
\hline \multicolumn{5}{|c|}{$\ln ($ \$volume $)=\alpha_{0}++\alpha_{1} \mathrm{AM}+\alpha_{3}$ lnmve $+\alpha_{4} \mathrm{NT}+\alpha_{5} \mathrm{Cum}+\varepsilon_{i t}$} \\
\hline \multicolumn{5}{|c|}{$\begin{array}{l}\text { The first hypothesis } \\
\text { (Accrual-based earnings management based on modified Jones model and a measure of liquidity) }\end{array}$} \\
\hline VIF & P-value & T statistic & Variable factor & Variable \\
\hline- & $0 / 000$ & $27 / 77$ & $19 / 8672$ & Source width \\
\hline $1 / 01$ & $0 / 015$ & $-2 / 49$ & $-0 / 1451$ & $\begin{array}{l}\text { Management commitment } \\
\text { profit (adjusted Jones } \\
\text { model) }\end{array}$ \\
\hline $1 / 01$ & 0/099 & $1 / 67$ & $0 / 0792$ & $\begin{array}{l}\text { Natural logarithm value of } \\
\text { ordinary shares at end of } \\
\text { period }\end{array}$ \\
\hline $1 / 01$ & $0 / 000$ & $4 / 62$ & $0 / 00001$ & NT \\
\hline $1 / 01$ & $0 / 001$ & $-3 / 32$ & $-0 / 3834$ & Cum \\
\hline \multicolumn{4}{|c|}{$0 / 000$} & Probability of F statistics \\
\hline \multicolumn{4}{|c|}{$18 / 27$} & F statistic \\
\hline \multicolumn{4}{|c|}{$0 / 3457$} & $\begin{array}{l}\text { Adjusted coefficient of } \\
\text { determination } \mathrm{R}^{2}\end{array}$ \\
\hline
\end{tabular}


As the image (7) is observed, the significant level of accrual earnings management variables (0.015) and coefficient (-0.1451) is. As a result, the first hypothesis that accrual-based earnings management based on modified Jones and stock liquidity Based on $\ln$ (\$ volume) that a stock is a measure of liquidity is measured, At a significance level of $95 \%$ is approved. This means that the variable accrual-based earnings management has a significant correlation with the liquidity is variable; It means that the accrual-based earnings management level in a company, the greater the risk of reduced liquidity. Our results are similar to most studies. [1,2] in their study concluded that increasing the accrual-based earnings management level, the possibility of reduced stock liquidity.

Table 8: The first hypothesis: Accrual-based earnings management based on Kothari and liquidity criteria

\begin{tabular}{|c|c|c|c|c|}
\hline \multicolumn{5}{|c|}{$\ln ($ Svolume $)=\alpha_{0}++\alpha_{1} \mathrm{AM}+\alpha_{3} \ln m v e+\alpha_{4} \mathrm{NT}+\alpha_{5} \mathrm{Cum}+\varepsilon_{i t}$} \\
\hline \multicolumn{5}{|c|}{$\begin{array}{l}\text { The first hypothesis } \\
\text { (Accrual-based earnings management based on Kothari and liquidity criteria) }\end{array}$} \\
\hline VIF & P-value & T statistic & Variable factor & Variable \\
\hline - & $0 / 000$ & $27 / 78$ & $20 / 0113$ & Source width \\
\hline $1 / 01$ & $0 / 016$ & $-2 / 46$ & $-0 / 224$ & $\begin{array}{c}\text { Accrual earnings management } \\
(\text { (Kothari) }\end{array}$ \\
\hline $1 / 02$ & $0 / 149$ & $1 / 46$ & 0/0699 & $\begin{array}{l}\text { Natural logarithm value of } \\
\text { ordinary shares at end of } \\
\text { period }\end{array}$ \\
\hline $1 / 01$ & $0 / 000$ & $4 / 51$ & $0 / 00001$ & NT \\
\hline $1 / 01$ & $0 / 001$ & $-3 / 49$ & $-0 / 4242$ & Cum \\
\hline \multicolumn{4}{|c|}{$0 / 000$} & Probability of F statistics \\
\hline \multicolumn{4}{|c|}{$15 / 71$} & F statistic \\
\hline \multicolumn{4}{|c|}{$0 / 3459$} & $\begin{array}{l}\text { Adjusted coefficient of } \\
\text { determination } R^{2}\end{array}$ \\
\hline
\end{tabular}

As in Table 8, a significant level of accrual earnings management variables (0.016) and coefficient $(-0.244)$ is. As a result, the first hypothesis that accrual-based earnings management based on modified Jones and stock liquidity Based on $\ln (\$$ volume) that a stock is a measure of liquidity is measured, at a significance level of 95 percent approval will be, will become. This means that the variable accrual-based earnings management has a significant correlation with variable liquidity, i.e. the level of accrual-based earnings management in a company is more likely to reduce liquidity. Our results are similar to most studies. [1,2] in their study concluded that increasing the accrual-based earnings management level, the possibility of reduced stock liquidity.

Table 9: The second hypothesis (the actual management of earnings and a measure of liquidity)

\begin{tabular}{|c|c|c|c|c|}
\hline \multicolumn{5}{|c|}{$\mathrm{Pzr}=\alpha_{0}++\alpha_{1} R M+\alpha_{3}$ lnmve $+\alpha_{4} \mathrm{NT}+\alpha_{5} \mathrm{Cum}+\varepsilon_{i t}$} \\
\hline \multicolumn{5}{|c|}{ The second hypothesis (the actual management of earnings and a measure of liquidity) } \\
\hline VIF & P-value & T statistic & Variable factor & Variable \\
\hline- & $0 / 002$ & $3 / 15$ & $0 / 2490$ & Source width \\
\hline $1 / 09$ & $0 / 010$ & $2 / 61$ & $0 / 0170$ & $\begin{array}{l}\text { Actual management } \\
\text { profit }\end{array}$ \\
\hline $1 / 02$ & $0 / 098$ & $-1 / 67$ & $-0 / 0077$ & $\begin{array}{l}\text { Natural logarithm value } \\
\text { of ordinary shares at end } \\
\text { of period }\end{array}$ \\
\hline $1 / 09$ & $0 / 026$ & $-2 / 25$ & $-0 / 0000001$ & NT \\
\hline $1 / 01$ & $-0 / 745$ & $-0 / 33$ & $-0 / 0057$ & Cum \\
\hline \multicolumn{4}{|c|}{$0 / 0018$} & Probability of F statistics \\
\hline \multicolumn{4}{|c|}{$4 / 65$} & F statistic \\
\hline \multicolumn{4}{|c|}{$0 / 0743$} & $\begin{array}{l}\text { Adjusted coefficient of } \\
\text { determination R2 }\end{array}$ \\
\hline
\end{tabular}


As in Table 9 can be seen, the actual management of a significant variable interest $(0.010)$ and coefficient (0.0170) is. As a result, the second hypothesis at a significance level of $95 \%$ is approved. This means that the actual management variable interest has a direct correlation with the lack of liquidity is variable, i.e. the actual management of a company's profits over the likelihood of increased lack of liquidity. Our results are similar to most studies. [1,2] in their study concluded that by increasing the level of accrual-based earnings management, the probability of increased stock liquidity.

Table 10: The second hypothesis (the actual management of earnings and a measure of liquidity)

\begin{tabular}{|c|c|c|c|c|}
\hline \multicolumn{5}{|c|}{$\ln (\$$ volume $)=\alpha_{0}++\alpha_{1} R M+\alpha_{3} \ln$ ve $+\alpha_{4} \mathrm{NT}+\alpha_{5} \mathrm{Cum}+\varepsilon_{i t}$} \\
\hline The second hypothesis (the actual management of earnings and a measure of liquidity) \\
\hline VIF & P-value & T statistic & Variable factor & Variable \\
\hline- & $0 / 000$ & $26 / 20$ & $19 / 8365$ & Source width \\
\hline $1 / 09$ & $0 / 640$ & $-0 / 47$ & $-0 / 0174$ & $\begin{array}{c}\text { Actual management } \\
\text { profit }\end{array}$ \\
\hline $1 / 02$ & $0 / 128$ & $1 / 53$ & $0 / 0766$ & $\begin{array}{c}\text { Natural logarithm value } \\
\text { of ordinary shares at end } \\
\text { of period }\end{array}$ \\
\hline $1 / 09$ & $0 / 000$ & $4 / 84$ & $0 / 00002$ & NT \\
\hline $1 / 01$ & $0 / 002$ & $-3 / 21$ & $-0 / 4015$ & Cum \\
\hline \multicolumn{7}{|c|}{$0 / 000$} & & $\begin{array}{c}\text { Adjusted coefficient of } \\
\text { determination R2 }\end{array}$ \\
\hline \multicolumn{7}{|c|}{$0 / 3205$} \\
\hline
\end{tabular}

As in Table 10 can be seen, the actual management of a significant variable interest $(0.640)$ and coefficient (-0.0174) is. The second hypothesis is that stock liquidity Based on $\ln (\$$ volume) that a stock is a measure of liquidity measure, which rejected at a significance level of $95 \%$. This means that the actual management of the variable associated with the variable liquidity is insignificant and reverse.

\section{CONCLUSION}

One of the characteristics of the ideal efficient market, no transaction costs, and therefore high liquidity; Therefore, it can be a measure of the efficiency of market liquidity, particularly in terms of the information presented. And widely used in the examination of the factors used to present information [1]. With increased liquidity, transaction costs will drop dramatically. Liquidity also plays an important role in the price discovery process. The concept of fledgling markets such as market liquidity in Iran is very important. The results of research in the field of liquidity in the securities market is Iran, shows that investors lack of liquidity risk in their decisions in terms of their intensity. after investigating the factors affecting the liquidity of the utmost importance. Among the factors that could affect liquidity, earnings management. As the company's earnings management in selecting accounting policies to achieve some specific goals defined administrator. The effect of accrual-based earnings management and gain real management on liquidity and lack of liquidity stocks were examined. Our results suggest that the accrual-based earnings management by the lack of liquidity of a significant relationship, and there is a significant inverse relationship with stock liquidity. The benefit of the actual management of a significant relationship with the lack of stock liquidity, and the liquidity and there is an inverse relationship insignificant. Finally, it is suggested that other criteria should be used to measure stock liquidity and earnings management. The study also suggested that industry be investigated separately in Tehran Stock Exchange. 


\section{References}

[1] Chung, K. Elder, J, Kim, J., (2008), "Corporate Governance and Liquidity", journal of Financial and Quantitative Analysis.

[2] Cohen D. A., Zarowin P. (2008)."Accrual- Based and Real Earnings Management activities around Seasoned Equity Offerings". working paper, Available at http://ssrn.com/abstract=1081939.

[3] Dechow, P. M., Sloan, R. G., and Sweeney, A. P.(1995). Detecting earnings management Accounting Review, 70: 193-225.

[4] Dye R. Earnings management in an overlapping generations model. Journal of Accounting Research 1988; 26:195-235.

[5] García, J.M,and G.Beatriz andF. Penalva. (2012). Accounting conservatism and the limits to earnings management http://ssrn.com/abstract=2165694.

[6] Goss, Barry A. (2008). "Debt, Risk and Liquidity in Futures Markets", Routledge, New York.

[7] Healy, P. M., and Wahlen, J. M.(1999). A review of the earnings management literat and its implications for standard setting. Accounting Horizons, 13: 365-383.

[8] Jones, J. J. (1991). Earnings management during import relief investigations. Journal of Accounting Research 29 (2): 193-228.

[9] Kothari, S.P., A.J. Leone, and C.E. Wasley.(2005). Performance matched discretional accruals measures. Journal of Accounting and Economics 39: 163-197.

[10] Roychowdhury,S.(2006). Management of earnings through the manipulation of rea activities thataffect cash flow from operations. Journal of Accounting and Economics 42 (3): 335-370.

[11] Schipper, K. (1989). Commentary on earnings management. Accounting Horizons, 3: 91- 12.

[12] Zang, A. Y.(2012). Evidence on the trade-off between real activities manipulation and accrual based earnings management. The Accounting Review87 (2): 675-703. 